\title{
Evaluation of delirium in aged patients assisted at emergency hospital service
}

\author{
Avaliação do delirium em idosos atendidos em um serviço hospitalar de emergência \\ Evaluación del delirium en pacientes ancianos tratados en un servicio hospitalario de urgencias
}

Isabella Cristina Barduchi Ohl'

ORCID: 0000-0003-0152-4845

Suzel Regina Ribeiro Chavaglia"

ORCID: 0000-0001-7033-0185

Rosali Isabel Barduchi Ohl' ORCID: 0000-0003-0369-1727

Maria Carolina Barbosa Teixeira Lopes' ORCID: 0000-0002-8989-4404

Cássia Regina Vancini Campanharo' ORCID: 0000-0002-7688-2674

Meiry Fernanda Pinto Okuno' ORCID: 0000-0003-4200-1186

Ruth Ester Assayag Batista' ORCID: 0000-0002-6416-1079

' Universidade Federal de São Paulo. São Paulo, São Paulo, Brazil. "Universidade Federal do Triângulo Mineiro. Uberaba, Minas Gerais, Brazil.

How to cite this article: Ohl ICB, Chavaglia SRR, Ohl RIB, Lopes MCBT, Campanharo CRV, Okuno MFP, et al. Evaluation of delirium in aged patients assisted at emergency hospital service.

Rev Bras Enferm. 2019;72(Suppl 2):153-60. doi: http://dx.doi.org/10.1590/0034-7167-2018-0386

Corresponding Author:

Rosali Isabel Barduchi Ohl

E-mail: rosaliohl@hotmail.com

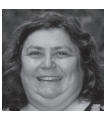

Submission: 06-12-2018

Approval: 02-26-2019

\section{ABSTRACT}

Objective: identify the occurrence of delirium in aged patients assisted in emergency services and verify its relationship with sociodemographic and clinical variables. Method: cross-sectional, prospective study with a quantitative approach. Two hundred aged hospitalized patients participated. The Confusion Assessment Method was used for data collection. For statistical analysis, chi-square tests, likelihood ratio and Fisher's test were used, with a significance level of $5 \%$. Results: male gender and mean age of 71.8 years were predominant. In the first 24 hours of hospitalization, $56(28 \%)$ aged individuals presented delirium. An association of the disease with lack of physical activity, presence of a caregiver, hypertension, dyslipidemia and cerebrovascular diseases was identified. Conclusion: Delirium was associated with no physical activity, the need of a caregiver, and the presence of comorbidities. The importance of conducting other studies that may lead to early identification of the condition to prevent its complications is emphasized. Descriptors: Delirium; Aged; Emergency Service Hospital; Nursing; Geriatric Assessment.

\section{RESUMO}

Objetivo: identificar a ocorrência de delirium em idosos atendidos em serviço de emergência e verificar sua relação com as variáveis sociodemográficas e clínicas. Método: estudo transversal, prospectivo, de abordagem quantitativa. Participaram 200 idosos internados. Para coleta de dados utilizou-se o instrumento Confusion Assessment Method. Para as análises estatísticas, utilizaram-se os testes qui-quadrado, razão de verossimilhança e teste de Fisher, com nível de significância de 5\%. Resultados: foram predominantes o sexo masculino e idade média de 71,8 anos. Nas primeiras 24 horas de internação, 56 (28\%) idosos apresentaram delirium. Foi identificada relação da doença com falta de prática de atividade física, presença de cuidador, hipertensão, dislipidemia e doenças cerebrovasculares. Conclusão: o delirium foi associado à não realização de atividade física, à necessidade de um cuidador e à presença de comorbidades. Ressaltase a importância da realização de outros estudos que possam levar à identificação precoce do quadro para prevenção de suas complicações.

Descritores: Delirium; Idoso; Serviço Hospitalar de Emergência; Enfermagem; Avaliação Geriátrica.

\section{RESUMEN}

Objetivo: identificar la ocurrencia de delirio en pacientes ancianos tratados en los servicios de urgencias y verificar su relación con variables sociodemográficas y clínicas. Método: estudio transversal prospectivo con enfoque cuantitativo. Participaron doscientos pacientes ancianos hospitalizados. Se utilizó el método de Confusion Assessment para la recopilación de datos. Para el análisis estadístico, se utilizaron testes de Chi-cuadrado, cociente de probabilidad y prueba de Fisher, con un nivel de significación del 5\%. Resultados: predominaron el sexo masculino y la edad media de 71,8 años. En las primeras 24 horas de hospitalización, $56(28 \%)$ ancianos presentaron delirio. Se identificó una relación entre la enfermedad y la falta de actividad física, la presencia de un cuidador, la hipertensión, la dislipidemia y las enfermedades cerebrovasculares. Conclusión: El delirio se asoció con la falta de actividad física, la necesidad de un cuidador y la presencia de comorbilidades. Se enfatiza la importancia de realizar otros estudios que puedan conducir a la identificación temprana de la afección para prevenir sus complicaciones.

Descriptores: Delirio; Anciano; Servicio de Urgencia en Hospital; Enfermería; Evaluación Geriátrica. 


\section{INTRODUCTION}

The aging of the population is a phenomenon that has occurred globally, both in the more developed and the less developed countries. In Brazil, the population over 60 years old amounts to more than 20 million people and this phenomenon grows every year ${ }^{(1)}$.

Estimates from the Brazilian Institute of Geography and Statistics (IBGE) indicate that, in 2040, the country's population will be about 230 million people, constituting the sixth population in the world with the largest number of aged - approximately 54 million $^{(1-2)}$.

The increase in life expectancy brings a series of challenges that health professionals and managers have been facing today. No matter how healthy the population aging process is, maintaining the quality of life of these aged people as integrated citizens in society, with autonomy, mobility, access to information, services, safety and preventive health, becomes an important problem to be overcome ${ }^{(1-2)}$.

Fragility is a frequent condition among the aged population, because they are more susceptible to diseases, disabilities and sequelae that will require effective and comprehensive actions of the health system. Among these weaknesses, one of the most prevalent chronic conditions among the aged population is the delirium.

Delirium is a neurological syndrome characterized by acute changes in the level of consciousness and cognitive function, which starts acutely and develops in a floating manner, rarely diagnosed and/or treated ${ }^{(3)}$. Most of the time, it is confused with emotional disorders, such as depression, because it affects perception, memory, orientation and reasoning, in addition to compromising the sleep-wake cycle, which can lead to delusional ideas and hallucinations $s^{(3-4)}$.

The causes of delirium are complex and multifactorial, including, as triggering factors, infection, sleep deprivation, pain, specific organic failures and metabolic disorders. Each individual's threshold for delirium differs in the predisposition of risk factors, such as age and fragility. Its prevalence in hospitalized patients increases with age and varies according to the diagnosis of hospitalization ${ }^{(5)}$.

This is considered the second most prevalent psychiatric syndrome in the hospital environment, after mood disorders, affecting from $29 \%$ to $64 \%$ of hospitalized patients, may occur in people of any age if the neurological impairment is extensive, and may affect up to $80 \%$ of patients admitted to intensive care units ${ }^{(6)}$.

The incidence of delirium is associated with high mortality, increased length of stay in critical units and longer duration of mechanical ventilation, in addition to durable functional and cognitive deficit. In the emergency services, it affects about $10 \%$ to $30 \%$ of the elders treated at the time of admission or during their hospitalization ${ }^{(7-8)}$.

Generally, the medical team is not assertive in the diagnosis of delirium, with an average accuracy of only $24 \%$ to $35 \%$ of cases among elders. The prevalence of elders with the disease could be even higher, because some patients are unable to communicate or cooperate and, thus, many are excluded from studies ${ }^{(8)}$.

Early and accurate diagnosis of the disease in the aged may be the prediction of a serious medical condition. The wrong diagnosis of delirium in the elders treated in emergency units can lead to early discharge, which increases mortality in the six months after hospital discharge. ${ }^{\left({ }^{8}\right)}$. Studies also indicate the existence of an association of delirium with a longer hospitalization period, worse prognosis, functional deterioration, higher risk of hospital mortality, dementia, institutionalization and recurrent hospitalizations $^{(3,9-10)}$.

The pathophysiology of delirium is not yet well understood, and its etiology is considered complex and multifactorial. Factors such as infection, sleep deprivation, pain, alcohol consumption, use of psychoactive drugs, malnutrition, metabolic disorders, among other comorbidities, may be triggering this disorder. The level of delirium differs individually among people, depending on the predisposing risk factors, such as age and fragility ${ }^{(3-4,9)}$. Thus, it is necessary to identify this disorder early in aged patients admitted to the emergency services, because delirium is considered a strong potential indicator of risk of death ${ }^{(3)}$.

Clinically, it is important to be aware that each key symptom of this chronic condition is strongly related to death, and the subjects who present only one symptom still represent an increased risk, thus highlighting the need to recognize each symptom separately. A better awareness of mortality risk associated with delirium would reinforce the arguments for early intervention, thus generating a better treatment and higher quality of patient care ${ }^{(3)}$.

There are many scales or instruments to help professionals to identify patients with delirium. However, it is recommended that these instruments consider the guidelines established in the Diagnostic and Statistical Manual of Mental Disorders (DSM-5) of the American Psychiatric Association (APA) and the International Statistical Classification of Diseases and Related Health Problems (ICD-10) of the World Health Organization as a reference standard ${ }^{(10)}$.

One of the main instruments derived from DSM-5 and widely used in emergency services in Brazil is the Confusion Assessment Method (CAM). CAM was validated for the Portuguese language, proving to be an adequate and reliable instrument to verify the presence of delirium, since it presented high levels of sensitivity (94.1\%) and specificity (96.4\%), high positive predictive values (84.2\%) and negative predictive values (98.8\%), suggesting that very few cases of the disease are not identified when the scale is systematically used ${ }^{(11-13)}$.

In a systematic review to evaluate the accuracy of instruments to evaluate the picture of delirium, 11 different instruments were compared, and the CAM scale was the standard instrument most used for clinical purposes and research over the past two decades. This instrument still stands out due to its high degree of specificity and sensitivity, and due to its accuracy, conciseness and ease of application ${ }^{(14-15)}$.

The emergency service is an environment where there is overcrowding, intense noise, disturbances and stress situations, and these factors may cause or even intensify the development of cognitive changes in patients, justifying the early detection of delirium in this service ${ }^{(16)}$.

\section{OBJECTIVE}

To identify the occurrence of delirium in aged patients assisted at the emergency department of a public teaching hospital in São Paulo city, and to verify the relationship of the disease with the sociodemographic and clinical variables identified in these subjects. 


\section{METHOD}

\section{Ethical aspects}

The research was conducted observing the Resolution No. $466 / 2012$ of the Ministry of Health - guidelines and norms that regulate research involving human beings - and the project was submitted for analysis and approval by the Committee of Ethics in Research of the Universidade Federal de São Paulo, under approval No. 965.524, CAAE 40675614.8.0000.5505.

\section{Design, place of study and period}

Cross-sectional and analytical study, carried out in the emergency department of a federal public university hospital in Sao Paulo city, 2016. The study included 200 aged hospitalized who met the research inclusion criteria.

\section{Inclusion and exclusion criteria}

The inclusion criteria of the study were: to be 60 years of age or older, with a maximum hospitalization time of 24 hours, and to agree to participate in the study by signing the Informed Consent Form. Patients with communication or language barriers and a previous diagnosis of dementia were excluded.

\section{Study protocol}

Sociodemographic and clinical data were obtained using a questionnaire prepared by the researchers containing information about age, gender, education, marital status, skin color, family income, presence of a caregiver, clinical conditions, comorbidities and life habits (physical activity, alcoholism, the medications used at home and at the emergency department).

To identify the delirium, the CAM was used, an instrument composed of nine variables: 1 - acute onset and floating course; 2 - inattention; 3 - disorganized thinking; 4 - altered level of consciousness; 5 - disorientation; 6 - memory impairment; 7 perception disturbances; 8 - psychomotor agitation; 9 - altered sleep-wake cycle.

The first four variables have greater specificity and sensitivity to detect the condition. Thus, the configuration of the delirium state is given by the mandatory presence of the first two characteristics associated with one of the last two ${ }^{(10)}$.

\section{Analysis of results and statistics}

The descriptive analysis of categorical variables was performed by calculating the frequency and percentage. For continuous variables, the mean, standard deviation, median, minimum and maximum were calculated. The association of sociodemographic variables was performed using the chi-square test and the likelihood ratio test. To associate clinical variables, outcomes and class of medications, the chi-square test and, when necessary, Fisher's exact test were used. A significance level of $5 \%$ ( $p$-value $<0.05)$ was used.

\section{RESULTS}

The study participants were predominantly male $(n=104.52 \%)$, with a mean age of $71.8 \pm 8.1$ years, married $(n=97.48 .5 \%)$, retired ( $n=158.79 \%)$, with incomplete basic education $(n=105.52 .5 \%)$, individual income between one and two minimum wages ( $\mathrm{n}$ $=121.60 .5 \%)$ and without caregiver $(n=133.66 .5 \%)$ (Table 1).

$56(28 \%)$ of the 200 study participants presented delirium, according to the application of CAM, in the first 24 hours of hospitalization. When relating the presence of delirium with the sociodemographic variables, it was observed that the only characteristic that presented statistical significance was the presence of a caregiver with the patient, so that those who did not have a caregiver had a higher percentage of absence of delirium $(p=0.0002)$ (Table 2$)$.

Table 1 - Sociodemographic characteristics of the elders hospitalized in the emergency department of a public teaching hospital, São Paulo, São Paulo, Brazil, 2018

\begin{tabular}{|c|c|c|}
\hline Characteristics & $\mathbf{n}$ & $\%$ \\
\hline \multicolumn{3}{|l|}{ Gender } \\
\hline Male & 104 & 52.0 \\
\hline Female & 96 & 48.0 \\
\hline \multicolumn{3}{|l|}{ Age } \\
\hline Mean (standard deviation) & $71.86(8.11)$ & \\
\hline Average & 71 & \\
\hline Minimum-maximum & $60-93$ & \\
\hline \multicolumn{3}{|l|}{ Marital status } \\
\hline Married & 97 & 48.5 \\
\hline Single & 12 & 6.0 \\
\hline Widower & 61 & 30.5 \\
\hline Divorced/separated & 30 & 15.0 \\
\hline \multicolumn{3}{|l|}{ Employment } \\
\hline Employee & 27 & 13.5 \\
\hline Unemployed & 7 & 3.5 \\
\hline Homemaker & 8 & 4.0 \\
\hline Retired & 158 & 79.0 \\
\hline \multicolumn{3}{|l|}{ Education } \\
\hline Illiterate & 11 & 5.5 \\
\hline Basic incomplete & 105 & 52.5 \\
\hline Basic complete & 50 & 25.0 \\
\hline High school complete & 22 & 11.0 \\
\hline College complete & 12 & 6.0 \\
\hline \multicolumn{3}{|c|}{ Family income in minimum wage (MW) } \\
\hline Less than $1 \mathrm{MW}$ & 3 & 1.5 \\
\hline From 1 to $2 \mathrm{MW}$ & 71 & 35.5 \\
\hline From 3 to $4 \mathrm{MW}$ & 91 & 45.5 \\
\hline More than $5 \mathrm{MW}$ & 35 & 17.5 \\
\hline \multicolumn{3}{|c|}{ Individual income in minimum wage (MW) } \\
\hline No income & 14 & 7.0 \\
\hline Less than $1 \mathrm{MW}$ & 6 & 3.0 \\
\hline From 1 to $2 \mathrm{MW}$ & 121 & 60.5 \\
\hline From 3 to $4 \mathrm{MW}$ & 48 & 24.0 \\
\hline More than $5 \mathrm{MW}$ & 11 & 5.5 \\
\hline \multicolumn{3}{|l|}{ Have a caregiver } \\
\hline No & 133 & 66.5 \\
\hline Yes & 67 & 33.5 \\
\hline Total & 200 & 100 \\
\hline
\end{tabular}


Table 2 - Association between the data obtained by the Confusion Assessment Method and the sociodemographic variables, São Paulo, São Paulo, Brazil, 2018

\begin{tabular}{|c|c|c|c|c|}
\hline \multirow[b]{2}{*}{ Characteristics } & \multicolumn{2}{|c|}{ Delirium (CAM)* } & \multirow{2}{*}{$\begin{array}{l}\text { Total } \\
\text { n (\%) }\end{array}$} & \multirow[b]{2}{*}{$p$ value } \\
\hline & Present n (\%) & Absent n (\%) & & \\
\hline \multicolumn{5}{|l|}{ Gender } \\
\hline Male & $27(26)$ & $77(74)$ & $104(52)$ & 0.5040 \\
\hline Female & $29(30.2)$ & $67(69.8)$ & $96(48)$ & \\
\hline \multicolumn{5}{|l|}{ Marital Status } \\
\hline Single & $23(23.7)$ & $74(76.3)$ & $97(48.5)$ & 0.5019 \\
\hline Widower & $5(41.7)$ & $7(58.3)$ & $12(6)$ & \\
\hline Divorced/separated & $19(31.1)$ & $42(68.9)$ & $61(30.5)$ & \\
\hline Single & $9(30)$ & $21(70)$ & $30(15)$ & \\
\hline \multicolumn{5}{|l|}{ Employment } \\
\hline Employee & $6(22.2)$ & $21(77.8)$ & $27(13.5)$ & 0.8813 \\
\hline Unemployed & $2(28.6)$ & $5(71.4)$ & $7(3.5)$ & \\
\hline Homemaker & $2(25)$ & $6(75)$ & $8(4)$ & \\
\hline Retired & $46(29.1)$ & $112(70.9)$ & $158(79)$ & \\
\hline \multicolumn{5}{|l|}{ Education } \\
\hline Illiterate & $2(18.2)$ & $9(81.8)$ & $11(5.5)$ & 0.1004 \\
\hline Basic incomplete & $33(31.4)$ & $72(68.6)$ & $105(52.5)$ & \\
\hline Basic complete & $15(39.5)$ & $23(40.5)$ & $50(25)$ & \\
\hline High school complete & $2(10.5)$ & $17(89.5)$ & $22(11.0)$ & \\
\hline College complete & $2(16.7)$ & $10(83.3)$ & $12(6)$ & \\
\hline \multicolumn{5}{|c|}{ Family income in minimum wage (MW) } \\
\hline No income/less than $1 \mathrm{MW}$ & $0(0)$ & $3(100)$ & $3(100)$ & 0.1120 \\
\hline From 1 to $2 \mathrm{MW}$ & $25(35.2)$ & $46(64.8)$ & $71(100)$ & \\
\hline From 3 to $4 \mathrm{MW}$ & $25(27.5)$ & $66(72.5)$ & $91(100)$ & \\
\hline More than $5 \mathrm{MW}$ & $6(17.1)$ & $29(82.9)$ & $35(100)$ & \\
\hline \multicolumn{5}{|c|}{ Individual income in minimum wage (MW) } \\
\hline No income & $5(35.7)$ & $9(64.3)$ & $14(7)$ & 0.4277 \\
\hline Less than $1 \mathrm{MW}$ & $1(16.7)$ & $5(83.3)$ & $6(3)$ & \\
\hline From 1 to $2 \mathrm{MW}$ & $37(30.6)$ & $84(69.4)$ & $121(60.5)$ & \\
\hline From 3 to $4 \mathrm{MW}$ & $12(25)$ & $36(75)$ & $48(24)$ & \\
\hline More than $5 \mathrm{MW}$ & $1(9.1)$ & $10(90.9)$ & $11(5.5)$ & \\
\hline \multicolumn{5}{|l|}{ Have a caregiver } \\
\hline No & $30(44.8)$ & $37(55.2)$ & $67(33.5)$ & 0.0002 \\
\hline Yes & $26(19.5)$ & $107(80.5)$ & $133(66.5)$ & \\
\hline Total & $56(28.0)$ & $144(72.0)$ & $200(100)$ & \\
\hline
\end{tabular}

Note: ${ }^{*}$ CAM: Confusion Assessment Method; MW: minimum wage.

Table 3 - Association between data obtained by Confusion Assessment Method and self-reported comorbidities, São Paulo, São Paulo, Brazil, 2018

\begin{tabular}{|c|c|c|c|c|}
\hline \multirow{2}{*}{ Comorbidities } & \multicolumn{2}{|r|}{ Delirium (CAM)* } & \multirow{2}{*}{$\begin{array}{l}\text { Total } \\
\text { n (\%) }\end{array}$} & \multirow{2}{*}{$p$ value } \\
\hline & Present n (\%) & Absent n (\%) & & \\
\hline \multicolumn{5}{|l|}{$\neq \mathrm{SAH}$} \\
\hline No & $28(41.8)$ & $39(58.2)$ & $67(100)$ & 0.0020 \\
\hline Yes & $28(21.1)$ & $105(78.9)$ & $133(100)$ & \\
\hline Total & $56(28)$ & $144(72)$ & $200(100)$ & \\
\hline \multicolumn{5}{|l|}{ Diabetes mellitus } \\
\hline No & $37(29.1)$ & $90(70.9)$ & $127(100)$ & 0.6376 \\
\hline Yes & $19(26)$ & $54(74)$ & $73(100)$ & \\
\hline Total & $56(28)$ & $144(72)$ & $200(100)$ & \\
\hline \multicolumn{5}{|l|}{ Dyslipidemia } \\
\hline No & 45 (34.6) & 85 (65.4) & $130(100)$ & 0.0045 \\
\hline Yes & $11(15.7)$ & $59(84.3)$ & 70 (100) & \\
\hline Total & $56(28)$ & $144(72)$ & $200(100)$ & \\
\hline \multicolumn{5}{|c|}{ Cerebrovascular diseases } \\
\hline No & $47(25.8)$ & $135(74.2)$ & $182(100)$ & 0.0293 \\
\hline Yes & $9(50)$ & $9(50)$ & $18(100)$ & \\
\hline Total & $56(28)$ & $144(72)$ & $200(100)$ & \\
\hline
\end{tabular}

Note: *CAM: Confusion Assessment Method; $¥ S A H$ : systemic arterial hypertension. 
Table 4 - Association between the data obtained by Confusion Assessment Method and life habits of physical activity and alcoholism, São Paulo, São Paulo, Brazil, 2018

\begin{tabular}{|c|c|c|c|c|}
\hline & \multicolumn{2}{|c|}{ Delirium (CAM)* } & \multirow{2}{*}{ Total } & \multirow{2}{*}{$p$ value } \\
\hline & Present n (\%) & Absent $\mathbf{n}(\%)$ & & \\
\hline \multicolumn{5}{|l|}{ Do physical activity } \\
\hline Yes & $0(0)$ & $18(100)$ & $18(100)$ & \multirow[t]{3}{*}{0.0055} \\
\hline No & $56(30.8)$ & $126(69.2)$ & $182(100)$ & \\
\hline Total patients & $56(28)$ & $144(72)$ & $200(100)$ & \\
\hline \multicolumn{5}{|l|}{ Frequency } \\
\hline 1 time/week & $0(0)$ & $1(100)$ & $1(100)$ & \multirow[t]{7}{*}{-} \\
\hline 2 times/week & $0(0)$ & $4(100)$ & $4(100)$ & \\
\hline 3 times/week & $0(0)$ & $4(100)$ & $4(100)$ & \\
\hline 4 times/week & $0(0)$ & $4(100)$ & $4(100)$ & \\
\hline 5 times/week & $0(0)$ & $3(100)$ & $3(100)$ & \\
\hline More than 5 times & $0(0)$ & $2(100)$ & $2(100)$ & \\
\hline Total patients & $0(0)$ & $18(100)$ & $18(100)$ & \\
\hline \multicolumn{5}{|c|}{ Use of alcohol in the last month } \\
\hline Yes & $4(25)$ & $12(75)$ & $16(100)$ & \multirow[t]{3}{*}{$1.0000^{*}$} \\
\hline No & $52(28.3)$ & $132(71.7)$ & $184(100)$ & \\
\hline Total patients & $56(28)$ & $144(72)$ & $200(100)$ & \\
\hline
\end{tabular}

Note: *CAM: Confusion Assessment Method.

Table 5 - Association between the data obtained by Confusion Assessment Method and the medications in use, São Paulo, São Paulo, Brazil, 2018

\begin{tabular}{lcccc}
\hline Medications & \multicolumn{2}{c}{ Delirium (CAM)* } & Total & p value \\
& Present $\mathbf{n}(\%)$ & Absent $\mathbf{n}(\%)$ & $\mathbf{n}(\%)$ & \\
Used in the residence & & & & \\
Antihypertensives & & & & \\
$\quad$ No & $29(41.4)$ & $41(58.6)$ & $70(100)$ & 0.0019 \\
$\quad$ Yes & $27(20.8)$ & $103(79.2)$ & $130(100)$ & \\
$\quad$ Total & $56(28)$ & $144(72)$ & $200(100)$ & \\
Antiulcer & & & & \\
$\quad$ No & $42(34.4)$ & $80(65.6)$ & $122(100)$ & 0.0114 \\
$\quad$ Yes & $14(17.9)$ & $64(82.1)$ & $78(100)$ & \\
$\quad$ Total & $56(28)$ & $144(72)$ & $200(100)$ & \\
Used in hospital & & & & \\
Analgesics & & & & \\
$\quad$ No & $10(17.9)$ & $46(82.1)$ & $56(100)$ & 0.0463 \\
Yes & $46(31.9)$ & $98(68.1)$ & $144(100)$ & \\
Total & $56(28)$ & $144(72)$ & $200(100)$ & \\
\hline
\end{tabular}

Note: *CAM: Confusion Assessment Method.

The most prevalent self-reported comorbidities were systemic arterial hypertension $(n=133,66.5 \%)$, diabetes mellitus $(n=$ $73,36.5 \%)$ and dyslipidemia ( $n=70,35 \%)$. When associating comorbidities with delirium using CAM, statistical significance was observed with the variables systemic arterial hypertension, dyslipidemia and cerebrovascular diseases (Table 3).

By associating the CAM data with lifestyle habits, such as physical activity and alcoholism, it was found that all the elderly who had delirium ( $n=56,28 \%$ ) did not practice physical activity, with statistical significance $(p=0.0055)$. In relation to alcoholism, no correlation between alcohol consumption and the presence of delirium was identified (Table 4).

Regarding the use of medications, it was observed that, among all medications used, those patients who did not use antihypertensives and antiulcer drugs in their homes, as well as those who, during hospitalization, received analgesics, had a higher percentage of delirium, with statistical significance (Table 5).

\section{DISCUSSION}

Delirium is a cognitive alteration that, despite being cited more than 2,500 years ago, remains poorly understood. It is possible to avoid $30 \%$ to $40 \%$ of cases and, despite its low prevalence in the community, its presence generally leads to the search for a health service and costly expenses ${ }^{(13)}$.

The economic and sociodemographic profile of the participants, especially with respect to gender and age, coincides with the results found in the literature ${ }^{(3,5-8,10,13)}$. Particularly, in another recent research conducted with elders assisted in an emergency unit of a university hospital in Goiás and, despite presenting low prevalence in the community, its presence usually leads to the search for a health service and costly expenses ${ }^{(17)}$.

The predominance of male patients may be associated with higher morbidity and mortality in this population and the consideration that men are less careful about their health ${ }^{(17-18)}$.

The low level of education presented by the elders in this research suggests a stronger tendency to present health problems. A study conducted in Rio Grande do Sul observed that the lower the time of schooling, the higher the correlation with functional disability, both for basic activities of daily living and for instrumental activities. These correlations may also be related to the socioeconomic conditions of these elders, since, in Brazil, skin color and education are directly connected to the socioeconomic level of the population and, consequently, is associated to health conditions and lifestyle ${ }^{(19)}$.

The identification of systemic arterial hypertension (SAH) as the most prevalent comorbidity among the elders in this research is evidenced in studies indicating that the disease, with diabetes mellitus and other cardiocirculatory diseases, is one of the most frequent chronic-degenerative conditions among the elders in our country. SAH is among the main diseases that affect elders, being one of the main responsible for reducing the quality and expectation of life in this population ${ }^{(20-21)}$.

Among the participants in this study, 56 (28\%) patients presented delirium in the first 24 hours of hospitalization in the emergency department. Researchers from the Harvard Medicine School, USA, found that from $8 \%$ to $17 \%$ elders admitted in 
emergency services had delirium and that the longer the length of stay the higher the incidence of the disease and it can reach up to $50 \%$ of the hospitalized elders ${ }^{(13)}$.

Delirium was more prevalent in the elders who reported no physical activity, coinciding with researches that reported the association of physical activity with lower rates of cognitive decline and dementia. According to these studies, several neural mechanisms, which are stimulated by physical activity, such as angiogenesis, neurogenesis, release of neurotrophic factors (IGFI), brain-derived neurotrophic factor (BDNF) and neuroplasticity, act as neuroprotection factors ${ }^{(22-23)}$.

Elders who had no need of a caregiver, that is, whose functional capacity was preserved, had a lower percentage of delirium. Studies carried out with institutionalized and/or not institutionalized aged patients showed that those older patients with greater functional deficit depended more on the presence of a caregiver and presented greater cognitive decline $\mathrm{e}^{(24-25)}$.

The datum found in this research converge with those obtained in studies indicating that the main comorbidities associated with the presence of delirium are systemic arterial hypertension (SAH), dyslipidemia and cerebrovascular diseases ${ }^{(13,26)}$.

Although delirium is very common in elderly patients, its pathophysiology is still little known ${ }^{(10,13-14,27)}$. The literature shows that cardiovascular diseases, especially $\mathrm{SAH}$, have been associated with memory deficit, attention and abstract reasoning ${ }^{(5,7,9,23)}$. Concerning dyslipidemias, a study that showed an association with cognitive impairment was identified ${ }^{(28)}$.

Although the association between the use of analgesics and the presence of delirium was evidenced in this study, no evidence was found that could reaffirm this information, for this reason additional investigations are necessary in order to evidence this relationship. Studies indicating the use of sedatives and analgesics as risk factors for the development of delirium were carried out in intensive care units, where the great association of drugs and the dynamics of care is intense, but different from the environmental conditions in which this research was conducted ${ }^{(23,26,29-30)}$.

\section{Study limitations}

The limitations of this study are inherent to the cross-sectional design and to the fact that it described the reality of a single emergency department, not allowing generalization of the results obtained, nor the establishment of a cause and effect relationship between the variables investigated.

\section{Contributions to the area of nursing, health or public policy}

The results obtained in this research should contribute to the increase of scientific evidence related to delirium and, thus, we hope that they can minimize the risks to which the institutionalized elders are prone when admitted to the emergency services.

\section{CONCLUSION}

As a profile of the elders assisted in the emergency service found in this study, the male gender prevailed, mean age of 71.8 years, married, retired, who attended incomplete elementary school and had individual income between one and two minimum wages. A significant prevalence of delirium was identified among these elders during the first 24 hours of care in the emergency service.

The occurrence of delirium was associated with sedentarism, the need for a caregiver, the presence of systemic arterial hypertension, dyslipidemia and cerebrovascular diseases. Among the medications, analgesics were associated with the presence of delirium.

These elders need to receive a better care in their homes and, therefore, individualized care plans should be developed, in which strategies are implemented to reduce the costs associated with this disease and the deterioration of the quality of this population.

The results of this research pointed to the need to carry out more studies aiming the early detection and identification of risk factors for the development of delirium in these services, due to the significant prevalence found.

\section{REFERENCES}

1. Miranda GMD, Mendes ACG, Silva ALA. Population aging in Brazil: current and future social challenges and consequences. Rev Bras Geriatr Gerontol [Internet]. 2016 [cited 2018 May 12];19(3):507-19. Available from: http://www.scielo.br/pdf/rbgg/v19n3/pt_1809-9823-rbgg-19-03-00507.pdf

2. Abreu TA, Fernandes-Eloi J, Sousa AMBD. Reflections about of the psychosocial impacts of the institutionalization of the elderly persons in Brazil. Kairós Gerontol [Internet]. 2017 [cited 2018 May 12];20(2):333-52. Available from: https://revistas.pucsp.br/index.php/kairos/article/ view/35838/24649

3. Carrasco M, Zalaquett M. Delirium: an epidemic from the emergency department throughout the critical patient unit. Rev Med Clin Condes [Internet]. 2017 [cited 2017 Oct 16];28(2):301-10. Available from: https://doi.org/10.1016/j.rmclc.2017.04.019

4. Ribeiro SCL, Nascimento ERP, Lazzari DD, Jung W, Boes AA, Bertoncello KC. Knowledge of nurses about delirium in critical patients: collective subject discourse. Texto Contexto Enferm [Internet]. 2015 [cited 2016 Oct 18];24(2):513-20. Available from: http://dx.doi. org/10.1590/0104-07072015001702014

5. Diwell RA, Davis DH, Vickerstaff V, Sampson EL. Key components of the delirium syndrome and mortality: greater impact of acute change and disorganized thinking in a prospective cohort study. BMC Geriatrics [Internet]. 2018 [cited 2018 Apr 12];18:24. Available from: https:// doi.org/10.1186/s12877-018-0719-1

6. Richardson SJ, Davis DHJ, Stephan B, Robinson L, Brayne C, Barnes L, et al. Protocol for the Delirium and Cognitive Impact in Dementia (DECIDE) study: a nested prospective longitudinal cohort study. BMC Geriatrics [Internet]. 2017 [cited 2018 Apr 24]; 17:98. Available from: https://bmcgeriatr.biomedcentral.com/track/pdf/10.1186/s12877-017-0479-3 
Evaluation of delirium in aged patients assisted at emergency hospital service Ohl ICB, Chavaglia SRR, OhI RIB, Lopes MCBT, Campanharo CRV, Okuno MFP, et al.

7. Kuswardhani RAT, Sugi YS. Factors related to the severity of delirium in the elderly patients with infection. Gerontol Geriatr Med [Internet]. 2017 [cited 2018 Apr 25];3:1-5 Available from: https://www.ncbi.nlm.nih.gov/pmc/articles/PMC5686874/pdf/10.1177_2333721417739188.pdf

8. Gower LEJ, Gatewood MO, Kang CS. Emergency department management of delirium in the elderly. West J Emerg Med [Internet]. 2012 [cited 2016 Oct 18];13(2):194-201. Available from: https://www.ncbi.nlm.nih.gov/pmc/articles/PMC3415810/pdf/i1936-900X-13-2-194.pdf

9. Farias RG, Santos SMA. Determinants influence of aging active among elderly more elderly. Texto Contexto Enferm [Internet]. 2012 [cited 2016 Oct 18];21(1):167-76. Available from: http://www.scielo.br/pdf/tce/v21n1/a19v21n1.pdf

10. Oh ES, Fong TG, Hshieh TT, Inouye SK. Delirium in older persons: advances in diagnosis and treatment. JAMA [Internet]. 2017 [cited 2018 Apr 25];318(12):1161-74. Available from: http://facmed.otago.ac.nz/hspsychiatrytraining/wp-content/uploads/sites/3/2017/09/Deliriumupdate-JAMA-2017.pdf

11. Inouye SK, van Dyck CH, Alessi CA, Balkim S, Siegal AP, Horwitz Rl. Clarifying confusion: the confusion assessment method: a new method for detection of delirium. Ann Intern Med [Internet]. 1990 [cited 2016 Oct 18];113(12):941-8. Available from: http://citeseerx.ist.psu.edu/ viewdoc/download?doi=10.1.1.477.4525\&rep=rep1\&type=pdf

12. Fabbri RMA, Moreira MA, Garrido R, Almeida OP. Validity and reliability of the Portuguese version of the Confusion Assessment Method (CAM) for the detection of delirium in the elderly. Arq Neuropsiquiatr [Internet]. 2001 [cited 2016 Oct 18];59(2A):175-9. Available from: http://www.scielo.br/pdf/anp/v59n2A/a04v592a.pdf

13. Inouye SK, Westendorp RGJ, Saczynski JS. Delirium in elderly people. Lancet [Internet]. 2014 [cited 2018 Apr 26];383(9920):911-22. Available from: https://www.ncbi.nlm.nih.gov/pmc/articles/PMC4120864/pdf/nihms594934.pdf

14. Barron EA, Holmes J. Delirium within the emergency care setting, occurrence and detection: a systematic review. Emerg Med J [Internet]. 2013 [cited 2016 Oct 18];30(4):263-8. Available from: http://dx.doi.org/10.1136/emermed-2011-200586

15. Grover S, Kate N. Assessment scales for delirium: a review. World J Psychiatry [Internet]. 2012 [cited 2016 Oct 18];2(4):58-70. Available from: http://dx.doi.org/10.5498/WJP.v2.i4.58

16. Hare $M$, Arendts $G$, Wynaden $D$, Leslie $G$. Nurse screening for delirium in older patients attending the emergency department. Psychosomatics [Internet]. 2014 [cited 2016 Oct 18];55(3):235-42. Available from: http://dx.doi.org/10.1016/j.psym.2013.08.007

17. Oliveira CP, Santos IMG, Rocca AR, Dobri GB, Nascimento GD. Epidemiological profile of elderly patients treated in the emergency room of a university hospital in Brazil. Rev Med [Internet]. 2018 [cited 2018 May 5];97(1):44-50. Available from: http://dx.doi.org/10.11606/issn.16799836.v97i1p44-50

18. Sarmento SDG, Dantas RAN, Dantas DV, Oliveira SP, Henriques LMN, Costa IB. Profile of individuals with neurological disorders assisted by a prehospital mobile emergency care service. Cogitare Enferm [Internet]. 2017 [cited 2018 May 2];(22)2:e49698. Available from: http://www. saude.ufpr.br/portal/revistacogitare/wp-content/uploads/sites/28/2017/04/49698-204168-1-PB.pdf

19. Nunes JD, Saes MO, Nunes BP, Siqueira FCV, Soares DC, Fassa MEG, et al. Functional disability indicators and associated factors in the elderly: a population-based study in Bagé, Rio Grande do Sul, Brazil. Epidemiol Serv Saude [Internet]. 2017 [cited 2018 May 2];26(2):295-304. Available from: https://www.scielosp.org/pdf/ress/2017.v26n2/295-304/pt

20. Vieira CPB, Nascimento JJ, Barros SS, Luz MHBA, Valle ARMC. Self-reported prevalence, risk factors and hypertension control in older adults. Cienc Cuid Saude [Internet]. 2016 [cited 2018 May 2];15(3):413-20. Available from: http://ojs.uem.br/ojs/index.php/CiencCuidSaude/article/ view/28792/18281

21. Ferreira DN, Matos DL, Loyola Filho Al. Absence of routine medical consultation among hypertensive and/or diabetic elders: an epidemiological study based on the Brazilian National Household Survey 2008. Rev Bras Epidemiol [Internet]. 2015 [cited 2018 May 12];18(3):578-94. Available from: http://www.scielo.br/pdf/rbepid/v18n3/1415-790X-rbepid-18-03-00578.pdf

22. Buchman AS, Boyle PA, Yu L, Shah RC, Wilson RS, Bennett DA. Total daily physical activity and the risk of AD and cognitive decline in older adults. Neurology [Internet]. 2012 [cited 2016 Oct 18];78(17):1323-9. Available from: http://dx.doi.org/10.1212/WNL.0b013e3182535d35

23. Hopkins RO, Suchyta MR, Farrer TJ, Needham D. Improving post-intensive care unit neuropsychiatric outcomes. Am J Respir Crit Care Med [Internet]. 2012 [cited 2016 Oct 18];186(12):1221-8. Available from: http://dx.doi.org/10.1164/rccm.201206-1022CP

24. Trindade APNT, Barboza MA, Oliveira FB, Borges APO. Impact of cognitive decline in functional capacity in elderly institutionalized and noninstitutionalized. Fisioter Mov [Internet] 2013 [cited 2016 Oct 18];26(2):281-9. Available from: http://dx.doi.org/10.1590/S0103-51502013000200005

25. Dietrich C, Cardoso JR, Vargas F, Sanchez EC, Dutra FH, Moreira C, et al. Functional ability in younger and older elderlies after discharge from the intensive care unit: a prospective cohort. Rev Bras Ter Intensiva [Internet]. 2017 [cited 2018 May 10];29(3):293-302. Available from: http:// www.rbti.org.br/content/imagebank/pdf/0103-507X-rbti-29-03-0293.pdf

26. Zaal I, Devlin J, Peelen L, Slooter AJ. A systematic review of risk factors for delirium in the ICU. Crit Care Med [Internet]. 2015 [cited 2016 Oct 16];43(1):40-7. Available from: http://dx.doi.org/10.1097/CCM.0000000000000625

27. Carneiro JP, Cabral H. [Distinguishing dementia from depression in the elderly: a case report]. Rev Port Med Geral Fam [Internet]. 2016 [cited 2018 May 10];32(2):118-24. Available from: http://www.scielo.mec.pt/pdf/rpmgf/v32n2/v32n2a06.pdf Portuguese

28. Bueno DRS, Belintani DC, Borim FSA, Guariento ME. Factors associated with cognitive performance of non-demented elderly outpatients. Pan Am J Aging Res [Internet]. 2016 [cited 2018 May 10];4(1):5-11. Available from: http://dx.doi.org/10.15448/2357-9641.2016.1.23159

29. Mori S, Takeda JRT, Carrara FSA, Cohrs CR, Zanei SSV, Whitaker IY. Incidence and factors related to delirium in an intensive care unit. Rev EsC Enferm USP [Internet]. 2016 [cited 2018 May 10];50(4):585-91. Available from: http://dx.doi.org/10.1590/S0080-623420160000500007 
30. Faustino TN, Pedreira LC, Freitas YS, Silva RMO, Amaral JB. Prevention and monitoring of delirium in older adults: an educational intervention. Rev Bras Enferm [Internet]. 2016 [cited 2018 Aug 16];69(4):725-32. Available from: http://dx.doi. org/10.1590/0034-7167.2016690416i 